\title{
A common genetic network underlies substance use disorders and disruptive or externalizing disorders
}

\author{
Mauricio Arcos-Burgos • Jorge I. Vélez $\cdot$ \\ Benjamin D. Solomon • Maximilian Muenke
}

Received: 7 October 2011/Accepted: 25 March 2012/Published online: 11 April 2012

(C) The Author(s) 2012. This article is published with open access at Springerlink.com

\begin{abstract}
Here we summarize evidence obtained by our group during the last two decades, and contrasted it with a review of related data from the available literature to show that behavioral syndromes involving attention deficit/ hyperactivity disorder (ADHD), externalizing disorders, and substance-use disorder (SUD) share similar signs and symptoms (i.e., have a biological basis as common syndromes), physiopathological and psychopathological mechanisms, and genetic factors. Furthermore, we will show that the same genetic variants harbored in different genes are associated with different syndromes and that non-linear interactions between genetic variants (epistasis) best explain phenotype severity, long-term outcome, and response to treatment. These data have been depicted in our studies by extended pedigrees, where ADHD, externalizing symptoms, and SUD segregate and co-segregate. Finally, we applied here a new formal network analysis using the set of significantly replicated genes that have been shown to be either associated and/or linked to ADHD, disruptive behaviors, and SUD in order to detect significantly enriched gene categories for protein and genetic interactions,
\end{abstract}

M. Arcos-Burgos $(\bowtie)$ · J. I. Vélez · B. D. Solomon ·

M. Muenke ( $\square)$

Medical Genetics Branch, National Human Genome Research Institute, National Institutes of Health, Building 35,

Room 1B-209, Bethesda, MD 20892-3717, USA

e-mail: arcosburgosm@mail.nih.gov

M. Muenke

e-mail: mamuenke@mail.nih.gov

M. Arcos-Burgos

Translational Genomics Group, Department of Translational Medicine, John Curtin School of Medical Research, ANU College of Medicine, Biology and Environment, The Australian National University, Canberra, ACT, Australia pathways, co-expression, co-localization, and protein domain similarity. We found that networks related to pathways involved in axon guidance, regulation of synaptic transmission, and regulation of transmission of nerve impulse are overrepresented. In summary, we provide compiled evidence of complex networks of genotypes underlying a wide phenotype that involves SUD and externalizing disorders.

\section{Introduction}

Complex phenotypes or traits result from a complicated interplay involving pleiotropy (production by a single gene of two or more effects), genetic heterogeneity (production of the same effect by two or more genes), epistasis (nonlineal genetic interactions), and environmental forces (Acosta et al. 2004). This type of trait exhibits a preferential familial clustering that cannot be explained by environmental causes alone, including shared cultural influences, and typically does not display patterns of Mendelian segregation (Acosta et al. 2004).

One of the best examples that demonstrate the way in which interacting effects can give rise to complex phenotypes is autoimmune disease (AID). Any chronic condition initiated by loss of immunological tolerance to self-antigens is considered an AID (Anaya 2010), part of a heterogeneous group of disorders that afflict specific target organs or multiple organ systems. Even though specific epidemiological, clinical, and pathological features define different AIDs, they have a number of clinical signs and symptoms in common. They also share pathophysiological mechanisms and genetic factors. Furthermore, it is possible to find in a single patient more than one AID. More interestingly, one pedigree might include a cluster of many 
affected individuals with different but related phenotypes (Anaya 2010). Mutations in one gene might be associated with several AIDs (Jin et al. 2010; Spritz 2011) and variants in two genes might converge in a cooperative interaction (epistasis) to outline a complex AID phenotype, as described in membranous nephropathy (Stanescu et al. 2011). Autoimmune diseases preferentially tend to affect females (i.e., they demonstrate a gender bias), share similar causal environmental agents, and several AIDs might respond to the same pharmacological treatment (Anaya 2010).

Evidence derived from several studies by our group suggests that common mental disorders of childhood and adolescence form a similar picture to that of the AIDs.

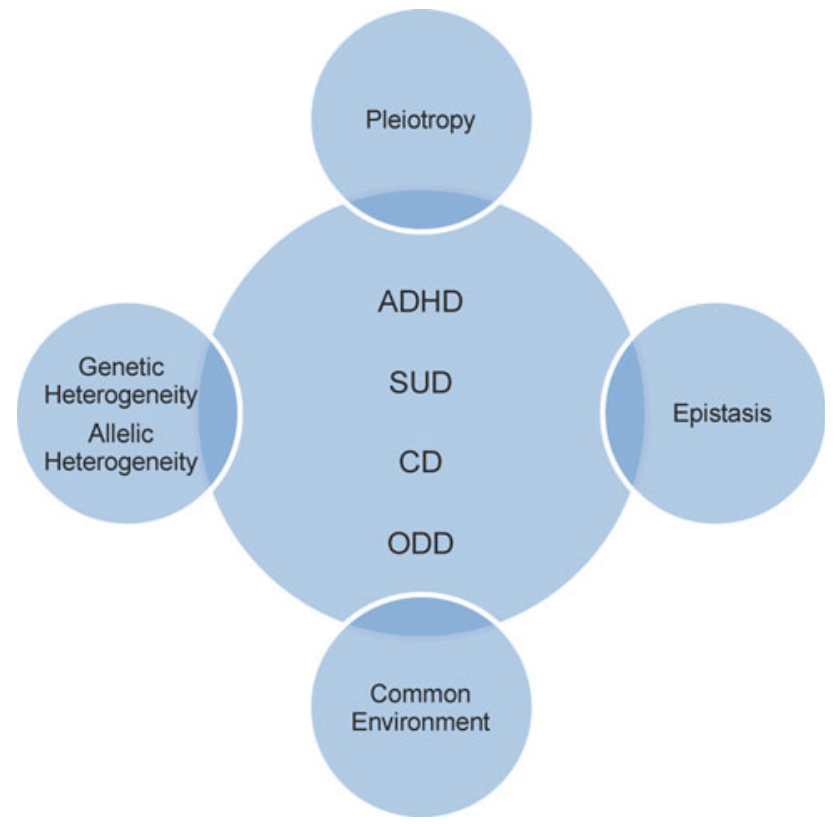

Fig. 1 Physiopathological and psychopathological mechanisms, and genetic factors shared by attention deficit hyperactivity disorder $(A D H D)$, conduct disorder $(C D)$, oppositional defiant disorder $(O D D)$ and substance-use disorder (SUD)
The Diagnostic and Statistical Manual of Mental Disorders (DSM-IV) includes in its classification attention deficit/ hyperactivity disorder (ADHD), disruptive behavior disorders including conduct disorder (CD) and oppositional defiant disorder (ODD), as well as substance-use disorder (SUD). In the following sections, we will present data that support our model proposing that these constructs, grouped under the label "externalizing disorders", can be considered to be related syndromes, and that they share common physiopathological and psychopathological mechanisms, with evidence for common underlying genetic factors (Fig. 1) (Acosta et al. 2004; Arcos-Burgos et al. 2004a, 2010; Elia et al. 2009; Jain et al. 2011; Martinez et al. 2011; Pineda et al. 2011; Ribases et al. 2011).

Furthermore, we show that same genetic variants, harbored at different genes (loci), may be associated with different syndromes (Arcos-Burgos and Muenke 2010; Jain et al. 2007) and, in particular cases, non-linear interactions between these variants (epistasis) correlate with the specific phenotype, the severity of that phenotype, the longterm clinical outcome, and response to treatment (Jain et al. 2011). In addition, we will demonstrate that in extended pedigrees, ADHD, externalizing symptoms, and SUD can all be present simultaneously in one individual, and also, that different members of a single pedigree can exhibit variable combinations of these syndromes (Fig. 2). Finally, by applying formal network analysis, we will show that these apparently unrelated genes are overrepresented by statistically significant gene ontology (GO) networks related to pathways such as those that involve axon guidance, regulation of synaptic transmission, and regulation of transmission of nerve impulse.

\section{Definitions and background}

Attention deficit/hyperactivity disorder is the most common neurodevelopmental behavioral disorder of childhood

Fig. 2 An extended pedigree demonstrating ADHD, externalizing symptoms, and associated conditions including nicotine, dependence and alcohol abuse and/or dependence. With modifications from Palacio et al. (2004)

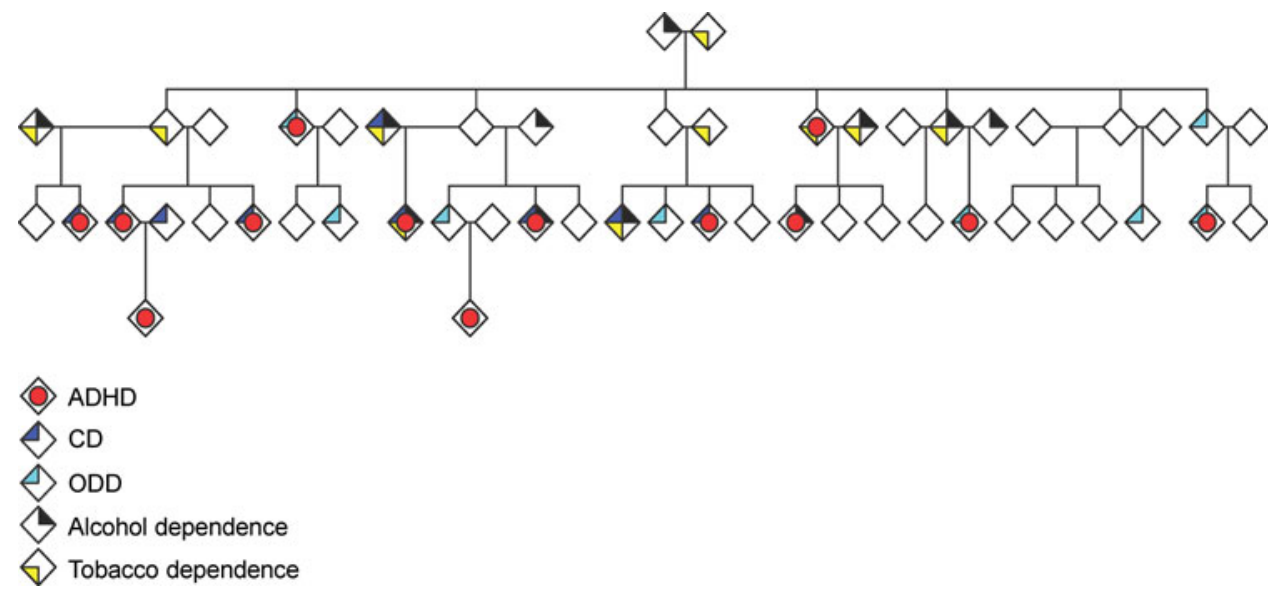


(Castellanos and Tannock 2002), and is characterized by elevated levels of inattention and/or hyperactive or impulsive behaviors that cause significant impairment (American Psychiatric Association 2000). Attention deficit/ hyperactivity disorder affects $10 \%$ of children and adolescents in the US (Visser et al. 2010); affected individuals are at increased risk for poor educational achievement, low income, underemployment, legal difficulties, and impaired social relationships (Arcos-Burgos et al. 2010). A conservative estimate of the annual societal cost of ADHD in childhood and adolescence is $\$ 42.5$ billion in the US alone (Pelham et al. 2007).

Other externalizing disorders of childhood besides ADHD include CD, ODD, and juvenile bipolar disorder. Although ADHD can occur as a single disorder in a minority of diagnosed individuals, it generally co-occurs with other disruptive behaviors disorders and with SUD (Palacio et al. 2004).

Substance-use disorder, a term that includes substance abuse and dependence, is characterized by compulsive drug seeking and drug use even in the face of severe adverse consequences. The World Health Organization estimates that there are at least 2 billion alcohol users, more than 1 billion tobacco users, and almost 185 million illicit drug users worldwide ( $\mathrm{Li}$ and Burmeister 2009). Vulnerability to addictions is a complex trait with strong genetic influences that are largely shared by abusers of different legal and illegal addictive substances (Karkowski et al. 2000; Liu et al. 2006; True et al. 1999; Tsuang et al. 1998; Uhl et al. 2001).

ADHD plus SUD: Individuals with ADHD are at increased risk for SUD (Bukstein 2008; Molina BSGM 1999; Szobot et al. 2007). Children diagnosed with ADHD monitored during the transition into adolescence exhibited higher rates of alcohol, tobacco, and psychoactive drug use than control groups of children without ADHD (Biederman et al. 1995; Molina and Pelham 2003). The lifetime risk for SUD is approximately $50 \%$ in subjects with childhood ADHD that persists into adulthood (Biederman et al. 1995). Similarly, a high ADHD prevalence is found in adolescents with SUD (DeMilio 1989; Horner and Scheibe 1997; Kuperman et al. 2001). Also, it affects SUD prognosis: $\mathrm{ADHD}$ is associated with both earlier and more frequent alcohol-related relapses (Ercan et al. 2003) and lower likelihood of cannabis treatment completion (White et al. 2004).

Regardless of the type of substance, longitudinal studies demonstrate that ADHD onset precedes SUD, suggesting that the psychopathology of ADHD is not typically secondary to SUD (Wilens and Biederman 2006). As ADHD precedes SUD, it is reasonable to hypothesize that timely diagnosis and treatment of ADHD may reduce the occurrence and/or severity of SUD. Indeed, in a recent metaanalysis of six studies in which children with ADHD were treated with stimulants, the most common pharmacotherapy, SUD was less common in adolescence in treated versus non-pharmacologically treated children (Wilens et al. 2003).

Though the basis of the connection remains unclear, several theories have been proposed to explain the increased risk for SUD in patients with ADHD. Genetically mediated personality traits, such as novelty seeking and impulsivity, are common to ADHD and SUD, and they may provide a link to common neurologic substrates (Chambers et al. 2003; Wilens and Biederman 2006). It has also been proposed that patients with ADHD use addictive substances in an attempt to self-medicate symptoms of the disorder (Khantzian 1997), and that the poor judgment and impulsivity associated with ADHD contribute to the development of dependence (Wilens and Biederman 2006).

\section{A proposed genetic network underlying ADHD, CD, ODD, and SUD}

Clustering of ADHD, CD, ODD, and SUD in pedigrees

In 18 extended multigenerational families recruited from the genetically isolated Paisa community in Colombia, we found that a high proportion of individuals were affected with ADHD (32.8\%). These families also had high rates of $\mathrm{CD} \quad(50 \% ; \quad \mathrm{OR}=11.5, \quad 95 \% \quad \mathrm{CI}=6.4-20.9)$, ODD $(25.4 \% ; \mathrm{OR}=2.7,95 \% \mathrm{CI}=1.5-4.8)$, and associated conditions, including nicotine, dependence and alcohol abuse and/or dependence (Fig. 2) (Palacio et al. 2004), which were often comorbid with ADHD.

\section{Linkage studies of ADHD}

We applied model-based and model-free linkage analyses and the pedigree disequilibrium test (PDT)(Martin et al. 2000) to genome-wide scan genotype data obtained for the Paisa families and found evidence of linkage to markers at chromosomes 4q13.2, 5q33.3, 8q11.23, 11q22, and 17p11 in individual families (Arcos-Burgos et al. 2004b). Fine mapping of these regions in the combined families resulted in significant linkage at chromosomes 4q13.2 (two-point allele sharing LOD score from $\mathrm{LODPAL}=4.44$ at D4S3248), 5q33.3 (two-point allele sharing LOD score from LODPAL $=8.22$ at D5S490), 11q22 (two-point allele sharing LOD score from $\mathrm{LODPAL}=5.77$ at D11S1998, multipoint NPL $-\log (P)=5.49$ at $\sim 128 \mathrm{cM})$ and 17p11 (multipoint NPL $-\log (P)>12$ at $\sim 12 \mathrm{cM}$, multipoint MLS $=2.48(\alpha=0.10)$ at $\sim 12 \mathrm{cM}$, two-point allele sharing LOD score from $\mathrm{LODPAL}=3.73$ at D17S1159). In addition, suggestive linkage at chromosome $8 q 11.23$ was found (combined two-point NPL $-\log (P)>3.0$ 
at D8S2332) (Arcos-Burgos et al. 2004b). Several of these regions were novel $(4 q 13.2,5 q 33.3$, and $8 \mathrm{q} 11.23)$ while others strongly replicated published loci $(11 \mathrm{q} 22$ and 17p11). In summary, we identified linkage to the same genomic regions in different pedigrees, and to several genomic regions in specific pedigrees. These findings are compatible with the effects of epistasis and pleiotropy, respectively. The strong concordance between different analytical methods of linkage and the replication of data between two independent studies suggest that these loci harbor ADHD susceptibility genes (Fig. 3) (Arcos-Burgos et al. 2004b).

Linkage and association commonalities of ADHD, CD, ODD, and SUD

Both linkage- and association-based genome scans have been conducted for specific drug dependencies as well as the vulnerability to addiction. While each study has identified many different loci, these data converge to likely represent true contributions of common allelic variants to polygenic models of genetic vulnerability to polysubstance abuse, and to some psychiatric conditions that share common manifestations (Fig. 4).

In the extended and multigenerational Paisa pedigrees segregating ADHD comorbidly with ODD, CD, alcohol abuse/dependence, and nicotine dependence, we found that ADHD co-segregates with disruptive behaviors as a phenotypically variable trait, as evidenced by highly significant pair-wise linkages among ADHD and ODD $(\mathrm{LOD}=14.19), \mathrm{ADHD}$ and $\mathrm{CD}(\mathrm{LOD}=5.34), \mathrm{ODD}$ and $\mathrm{CD}(\mathrm{LOD}=6.68)$, and $\mathrm{CD}$ and alcohol abuse/dependence ( $\mathrm{LOD}=3.98)$. In addition, we found evidence of linkage for comorbid ADHD phenotypes to loci at 8q24, 2p21-22.3, 5p13.1-p13.3, 12p11.23-13.3, 8q15, 11q22, and $14 \mathrm{q} 21.1-22.2$, suggesting that these patterns of cosegregation of ADHD with disruptive behavior and substance abuse comorbidities, and the linkage to similar regions, were indicative of a common major genetic cause (Jain et al. 2007). As additional evidence, some of these regions were highlighted by other studies, particularly the $11 \mathrm{q} 22$ chromosomal region that harbors the NCAM1, TTC12, ANKK1, and DRD2 genes (Table 1).

Evidence of linkage and association of ADHD, CD, ODD, and SUD to LPHN3

Using the integration of statistical and functional approaches, we discovered a novel gene that segregates with ADHD and contributes to disease susceptibility; this gene is harbored in the chromosome $4 \mathrm{q}$ region previously found to be linked to ADHD (Fig. 5). The application of fine mapping to these linked families sharpened the linkage signal and revealed new meiotic recombination events in individuals with ADHD, which further narrowed the minimal critical region with the gene to $\sim 20 \mathrm{Mb}$ (ArcosBurgos et al. 2010) (Fig. 5). Fine-scale genetic association was conducted in nuclear and large multigenerational Paisa families. Areas of interest included those that were generich or that included potential candidate genes, and were covered at a higher density (Arcos-Burgos et al. 2010). Using family-based association strategies and haplotypebased cladistic analysis, a significant area of association with ADHD was then defined by the single nucleotide polymorphic (SNP) markers rs1901223 and rs1355368 $\left(P=3.1 \times 10^{-3}\right.$, marker-based; $P=2.7 \times 10^{-5}$, haplotype based) (Arcos-Burgos et al. 2010) (Fig. 5).

The region of association was located at $62.4-62.7 \mathrm{Mb}$ (UCSC coordinates) on $4 \mathrm{q}$ within exons 4 through 19 of the Latrophilin3 gene (LPHN3) (Arcos-Burgos et al. 2010). Latrophilin3 is a member of the latrophilin (LPHN) subfamily of G-protein coupled receptors (GPCRs). Genes encoding the GPCRs, such as DRD4 and DRD5, have also been shown to be associated with ADHD (Arcos-Burgos et al. 2010) (Fig. 6a).

Latrophilins have seven transmembrane regions, a long $\mathrm{N}$-terminal extracellular sequences containing a 19-amino acid signal peptide (GPCR proteolytic site, GPS domain), and a serine/threonine-rich glycosylation region (Martinez et al. 2011). Latrophilins 1 and 2 serve as receptors for $\alpha$-latrotoxin, a component of the venom of the black widow spider (Martinez et al. 2011); this component interacts with neuronal GPCRs to stimulate exocytosis of GABAcontaining presynaptic vesicles. GABA is an inhibitory neurotransmitter. As LPHN3 is the most brain-specific latrophilin, it suggests a possible role in ADHD (Martinez et al. 2011) (Fig. 6b).

Once the study of Paisa families identified a specific region of the LPHN3 gene associated with ADHD, fine mapping was performed. This allowed us to precisely pinpoint variants in the DNA code that may alter function. In order to validate these findings, we pursued replication in additional samples from Colombia, Germany, Norway, Spain, and in two separate US populations. These metaanalyses showed evidence for a significant homogeneous genetic effect for three of the top associated markers inside the LPHN3 gene (Arcos-Burgos et al. 2010). Replication of the association of LPHN3 with ADHD in adults was also found in an independent sample from Spain (Ribases et al. 2010).

Combined efforts of this collaboration revealed potentially functional sequences within the LPHN3 gene that may be considered targets for future studies. These findings are thus not only a step toward a better understanding of 

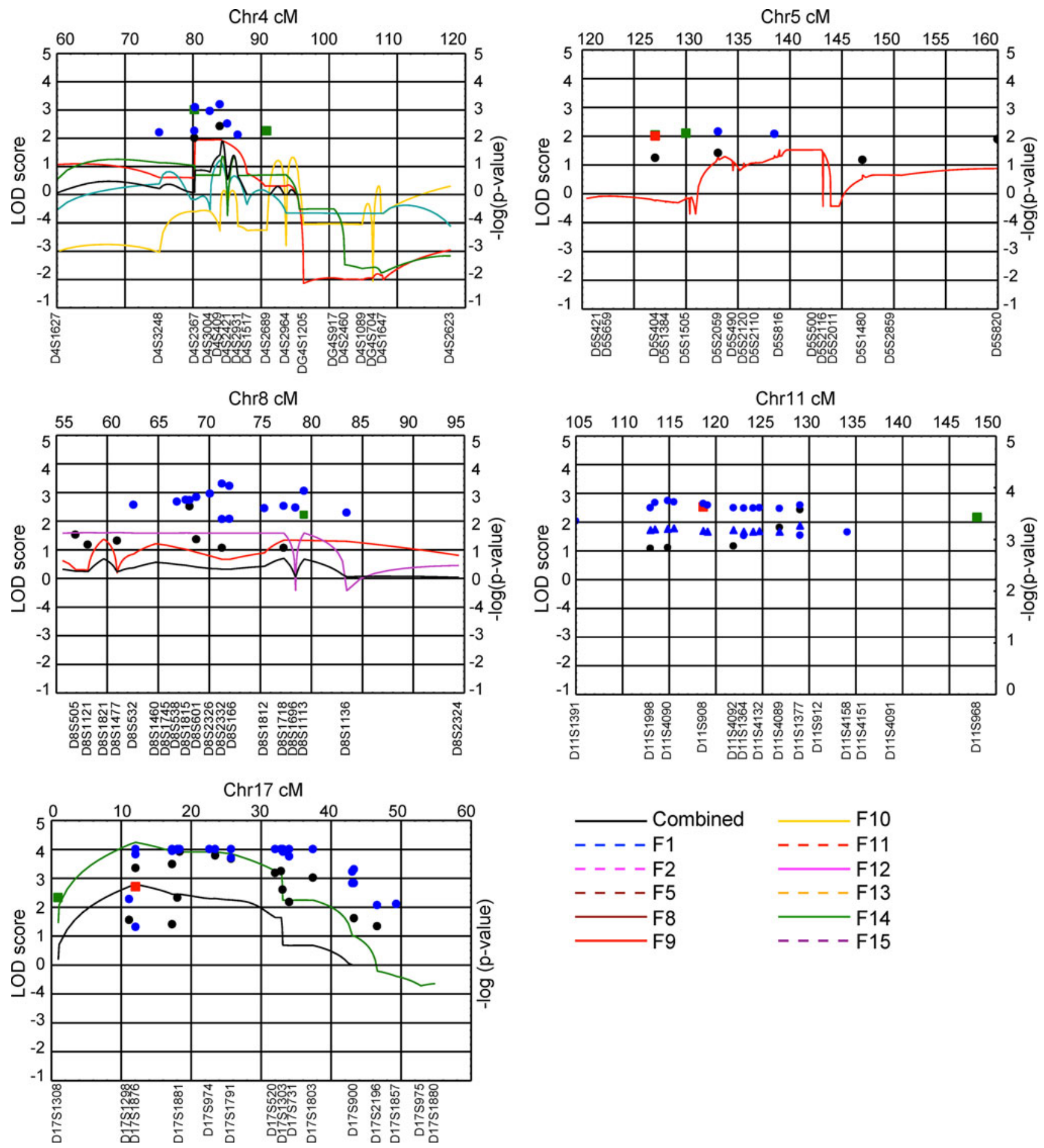

Fig. 3 Model-based and model-free linkage analyses in extended and multigenerational Paisa families found evidence of linkage to markers at chromosomes $4 \mathrm{q} 13.2,5 \mathrm{q} 33.3,8 \mathrm{q} 11.23,11 \mathrm{q} 22$, and $17 \mathrm{p} 11$. These results were compatible with the presence of epistasis and pleiotropy

in replication studies, suggesting that these loci harbor ADHD susceptibility genes. With modifications from Arcos-Burgos et al. (2004b)

ADHD, but also offer an example of how multidisciplinary groups can interact to dissect causes of genetically complex human diseases (Arcos-Burgos et al. 2010).

In addition to the genetic studies, we carried out pathologic studies of brain specimens and neuroimaging

studies. This showed that a key $L P H N 3$ variant of interest is expressed in brain regions related to attention and activity including the amygdala, caudate nucleus, cerebellum, and cerebral cortex. Importantly, the same variant associated with ADHD was also associated with response 


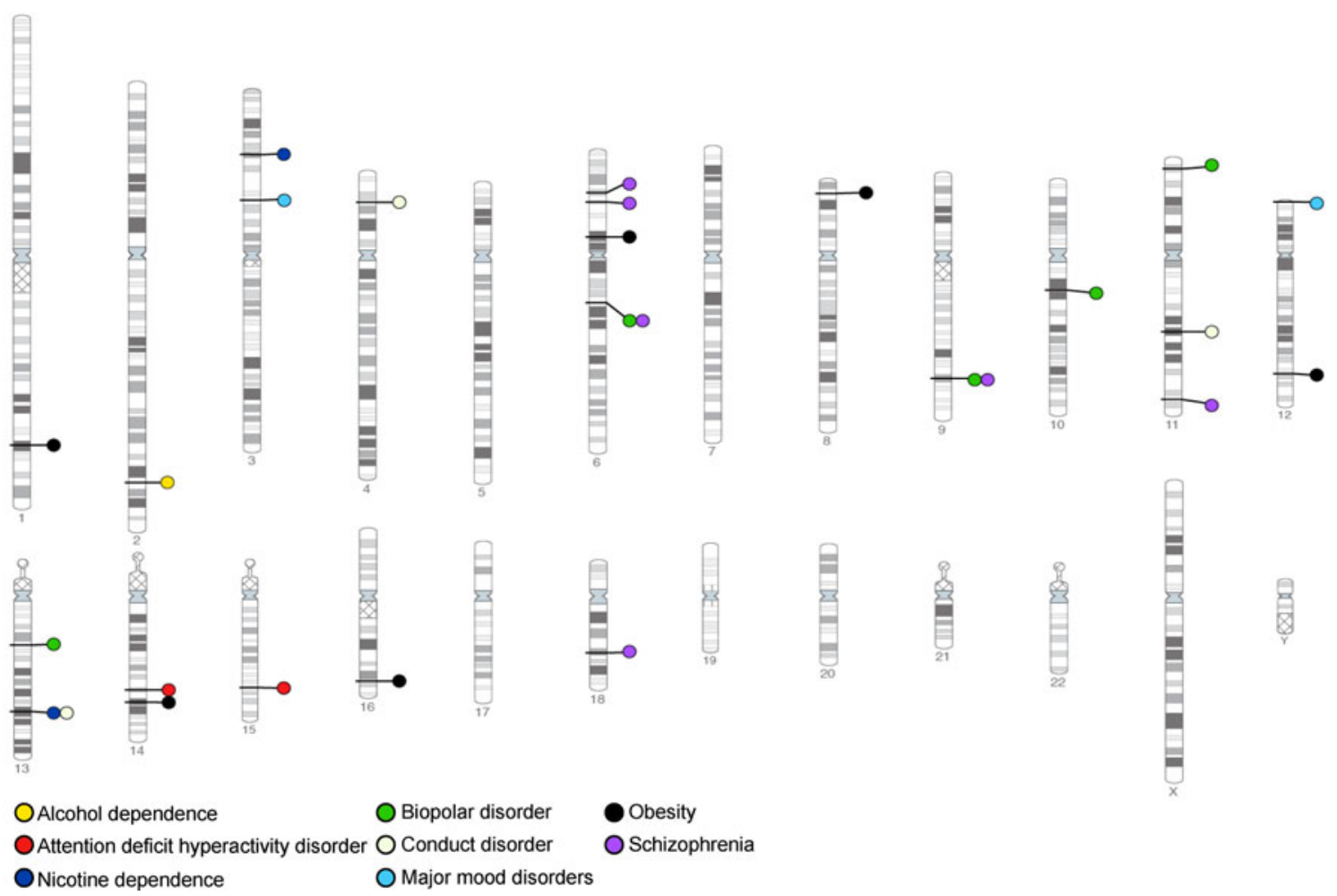

Fig. 4 Linkage- and association-based genome scans identified loci containing common allelic variants contributing to SUD and to some psychiatric conditions

Table 1 Results from GWAS and candidate gene approaches showing replicated genes associated with ADHD and SUD

\begin{tabular}{|c|c|c|c|c|c|c|}
\hline Trait & Chr. & Marker & $P$ value & Gene region & Type of study & Reference \\
\hline ADHD & 2 & rs 2556378 & $8.4 \times 10^{-7}$ & $B C L 11 A$ & GWAS case-control & $\begin{array}{l}\text { Hinney et al. } \\
\text { (2011) }\end{array}$ \\
\hline ADHD & 11 & rs5016282 & $1.8 \times 10^{-6}$ & GRM5 & GWAS case-control & $\begin{array}{l}\text { Hinney et al. } \\
\text { (2011) }\end{array}$ \\
\hline ADHD & 16 & rs8045006 & $2.3 \times 10^{-5}$ & $\mathrm{CDH} 13$ & GWAS case-control & $\begin{array}{l}\text { Neale et al. } \\
(2010)\end{array}$ \\
\hline $\begin{array}{l}\text { Smoking } \\
\text { behavior }\end{array}$ & 11 & rs10502172 & $9.1 \times 10^{-6}$ & $\begin{array}{l}\text { TTC12-ANKK1- } \\
\text { DRD2 }\end{array}$ & Candidate gene case-control association & $\begin{array}{l}\text { Ducci et al. } \\
\text { (2011) }\end{array}$ \\
\hline $\begin{array}{l}\text { Smoking } \\
\text { behavior }\end{array}$ & 15 & rs1051730, & $1.1 \times 10^{-5}$ & CHRNA3 & Candidate gene case-control association & $\begin{array}{l}\text { Ducci et al. } \\
\text { (2011) }\end{array}$ \\
\hline $\begin{array}{l}\text { Tobacco } \\
\text { smoking }\end{array}$ & 11 & $\begin{array}{l}\text { rs2303380-rs4938015- } \\
\quad \text { rs11604671 }\end{array}$ & $4.3 \times 10^{-2}$ & $\begin{array}{l}\text { TTC12-ANKK1- } \\
\text { DRD2 }\end{array}$ & $\begin{array}{l}\text { Candidate gene case-control } \\
\text { association, black and white } \\
\text { populations }\end{array}$ & $\begin{array}{l}\text { David et al. } \\
\text { (2010) }\end{array}$ \\
\hline $\begin{array}{l}\text { Alcohol } \\
\text { dependence }\end{array}$ & 11 & rs1893699-rs723077 & $2.1 \times 10^{-4}$ & $\begin{array}{r}\text { NCAM1, TTC12, } \\
\text { ANKK1, DRD2 }\end{array}$ & $\begin{array}{l}\text { Candidate gene case-control and } \\
\text { family-based association }\end{array}$ & $\begin{array}{l}\text { Yang et al. } \\
(2007 \text {, } \\
2008)\end{array}$ \\
\hline $\begin{array}{l}\text { Nicotine } \\
\text { dependence }\end{array}$ & 11 & $\begin{array}{l}\text { rs2303380-rs4938012- } \\
\text { rs4938015-rs11604671 }\end{array}$ & $1.0 \times 10^{-8}$ & $\begin{array}{r}\text { NCAM1-TTC12- } \\
\text { ANKK1-DRD2 }\end{array}$ & Candidate gene case-control association & $\begin{array}{l}\text { Gelernter } \\
\text { et al. (2006) }\end{array}$ \\
\hline
\end{tabular}

to stimulant medication (Arcos-Burgos et al. 2010). In other words, specific DNA sequence changes in the gene coding for LPHN3 were associated with and predicted whether or not a person with ADHD responded to and benefitted from treatment with stimulant medication.
LPHN3 is thus an example of a locus where multiple independent psychiatric studies converge, and recapitulates earlier findings involving SUD. Initially, alcohol abuse was linked to Chromosome 4 in the area of LPHN3 (Long et al. 1998). This study investigated a Southwestern American 


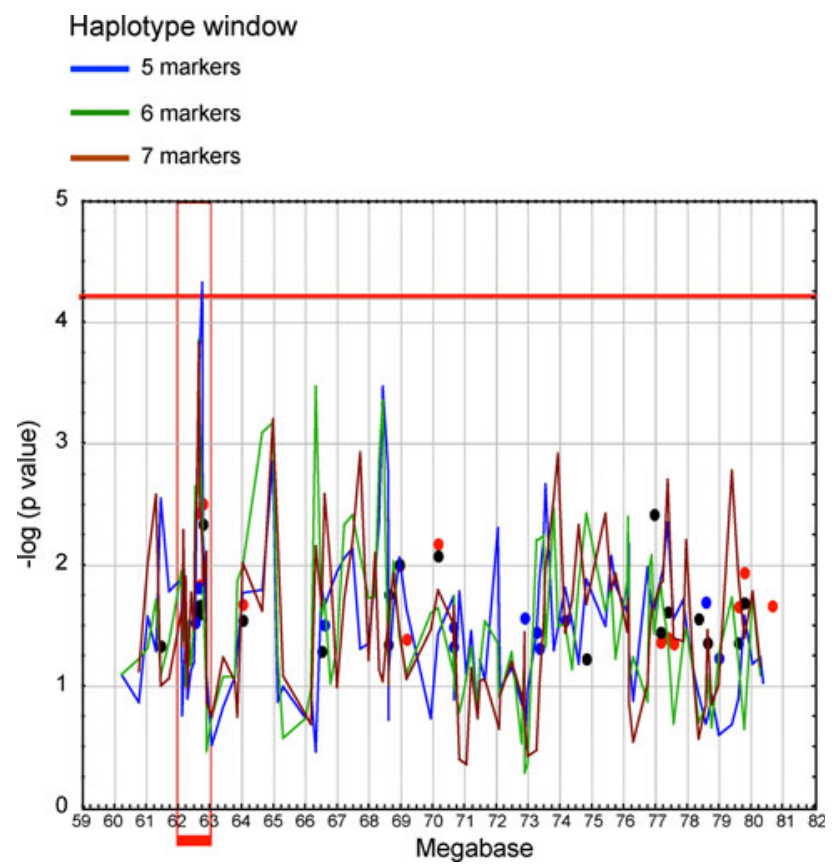

Fig. 5 ADHD mapping by LD using cladistic analyses with closely spaced SNP markers across the critical region in 137 additional nuclear families reveals an area of association between 62.4 and 62.7 $\mathrm{Mb}$ in chromosome 4 (in red). With modifications from ArcosBurgos et al. (2010)

Indian tribe by genome-wide linkage analysis and reported linkage to marker D4S1645, which is less than $300 \mathrm{~kb}$ upstream of LPHN3. Another independent study utilized two-point linkage analysis in families with alcohol dependence to identify a nominally significant locus at D4S244 (Reich et al. 1998), which is $\sim 5 \mathrm{Mb}$ downstream of LPHN3. While its distance from LPHN3 makes this latter report less compelling, it nonetheless suggests that there is a locus on chromosome $4 p$ related to alcohol dependence (Uhl 2004a, b).

Additional evidence is supplied by a third study that utilized whole genome association analysis to identify SNPs with significant allele frequency differences between abusers of illegal substances and control populations of both European-American (EA) and African-American (AA) ethnicities (Liu et al. 2006). This study identified three SNPs within $L P H N 3$ that are positive for association (Monte Carlo $P=5.89 \times 10^{-3}$ ). This group utilized this information and replicated these as well as additional LPHN3 SNPs in several populations including polysubstance abuser individuals from the National Institute on Drug Abuse (NIDA) (Bergen et al. 1999), samples from alcohol-dependent individuals from the Collaborative Studies on Genetics of Alcoholism (COGA) (Johnson et al. 2006; Liu et al. 2006), and samples from methamphetamine-dependent individuals from Japan and Taiwan (Uhl et al. 2008a, b).
We also provided evidence of epistasis underlying ADHD by screening for potential interactions between ADHD-linked loci, where we found a significant correlation between $4 \mathrm{q}$ and $11 \mathrm{q}\left(P<1 \times 10^{-8}\right)$ (Jain et al. 2011). Conditioning on the LPHN3 associated SNP, rs6551665, and using case-control and family-based designs, we detected interacting effects with a haplotype harbored on $11 \mathrm{q}\left(P<5 \times 10^{-6}\right)$. This haplotype encompasses Neural Cell Adhesion Molecule 1 (NCAMI), a gene with a fundamental role in neural development, the Dopamine Receptor D2 (DRD2), a gene previously associated with ADHD, and the Tetratricopeptide Repeat Domain 12 (TTC12), and Ankyrin repeat and Kinase Domain Containing 1 (ANKK1), two genes associated with externalizing symptoms and nicotine dependence (David et al. 2010; Ducci et al. 2011; Gelernter et al. 2006; Yang et al. 2007, 2008) (Table 1).

Using three additional ADHD datasets that previously showed the association of ADHD with LPHN3, the $L P H N 3-11 \mathrm{q}$ interaction was replicated by formal metaanalysis (Jain et al. 2011). The effect of the interaction represents a two-fold increase from the original risk conferred by $L P H N 3$ to develop ADHD (OR $=2.46$, $\left.95 \% \mathrm{CI}=1.63-3.70, P=5.09 \times 10^{-6}\right)$. In addition, the $L P H N 3-11 \mathrm{q}$ interaction more significantly demonstrates the effect that the LPHN3 susceptibility variant has on both ADHD response to stimulant medication and on brain metabolism (Jain et al. 2011). Furthermore, we demonstrated that this genetic interaction not only predicts ADHD severity but also long-term outcome, which is related to comorbidities (Acosta et al. 2011).

Evidence of linkage and association of the NCAM1-TTC12-ANKK1-DRD2 gene cluster to SUD

A prospective study of 4,762 finish subjects (52\% female) for whom smoking behaviors were ascertained at age 14 and 31 years, evaluated the developmental changes and the potential effect of genetic and non-genetic factors (Ducci et al. 2011). In this study, the A allele of rs 1051730 SNP marker, located in the Cholinergic Receptor alpha 3 (CHRNA3) gene, was found to have a similar effect-size at 14 years and 31 years and was more common in those described as heavy/regular smokers compared to those who did not smoke $\left(P=1.1 \times 10^{-5}\right)$.

Markers in the TTC12-ANKK1-DRD2 genomic region have been also associated with smoking behavior, with rs10502172 $\left(P=9.1 \times 10^{-6}\right)$ being the most significantly associated marker. This marker is located within the TTC12 gene; individuals with the $\mathrm{G}$ variant had $1.33(95 \% \mathrm{CI}=$ 1.11-1.60) times higher risk of being smokers at age 14, and 1.14 (95\% CI $=1.02-1.28$ ) times higher risk of being smokers at age 31 years. In adolescence, this variant also conferred increased risk of occasionally $(\mathrm{OR}=1.12,95 \%$ 
A

Latrophilin 3 (LPHN3)

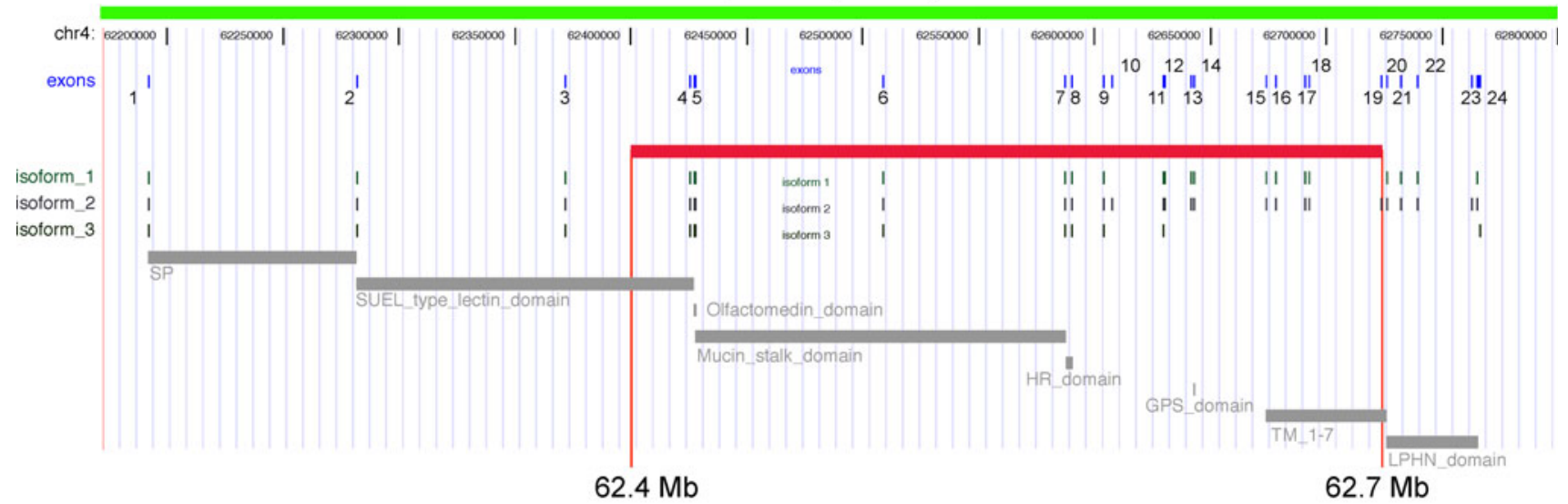

B

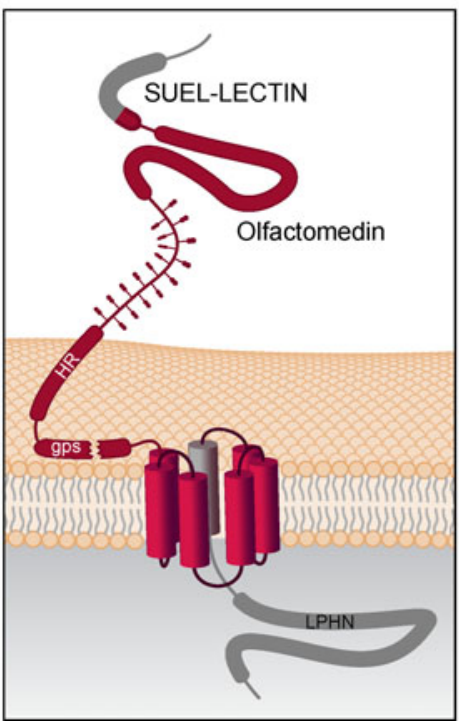

Fig. 6 a The susceptibility haplotype encompasses exons 4-19 of LPHN3, and contains important functional domains and variable splicing sites for isoforms of the gene. There are not other genes annotated over the region spanned by the susceptibility haplotype. b General structure of latrophilins. The long extracellular region

$\mathrm{CI}=1.12-1.48)$ smoking (Ducci et al. 2011). Furthermore, variants in the ANKK1 (rs2734849) and DRD2 (rs1076563) genes were also found to be significantly associated with smoking behavior.

In tobacco smoking, linkage studies and haplotypebased analyses on the TTC12-ANKK1-DRD2 gene cluster have also elucidated genetic and sex-specific associations with smoking behavior (David et al. 2010). Seven SNPs within this gene cluster were tested using longitudinal data from 1993 to 1994 and 2004 to 2005 in 638 individuals (including 270 individuals of black and 368 of white ethnicity) from the Baltimore Epidemiologic Catchment Area (ECA) cohort study. Evidence was provided for sexspecific differences in smoking behavior. First, black male contains four domains: a SUEL LECTIN domain, a region homologous to olfactomedins and myocilin, a homology region (HR) with BAI1-3, and a cysteine-rich GPCR proteolysis site (gps). With modifications from Arcos-Burgos et al. (2010)

smokers with the GTG haplotype (defined by the markers rs2303380-rs4938015-rs11604671) were more likely to stop smoking 11 years later (55.6\% GTG vs. $22.0 \%$ other haplotypes), in contrast with black women who had other haplotypes (20.8\% GTG vs. $24.0 \%$ other haplotypes). Conversely, the same haplotype (vs. other haplotypes) was significantly associated with a lifetime history of daily smoking $(\mathrm{OR}=1.6,95 \% \mathrm{CI}=1.1-2.4)$ and a higher prevalence of smoking initiation (77.6 \% GTG vs. $57.0 \%$ other haplotypes) in white individuals. Second, a different haplotype block was identified when comparing black and white individuals; this block consisted of one SNP within TTC12 (rs2303380) and three in ANKK1 (markers rs4938012, rs4938015, and rs11604671). 
As in tobacco behavior, case/control- and family-based haplotype analyses with 43 SNPs within the NCAM1TTC12-ANKK1-DRD2 gene cluster have been performed in studies of alcohol dependence (AD) (Yang et al. 2007) and drug dependence (DD) (Yang et al. 2008). In the first study, two separate association studies of AD were conducted on 1,220 individuals of EA ancestry using familybased (488 individuals) and case-control (732 individuals, $43.4 \%$ cases) designs (Yang et al. 2007). In this study, haplotypic variants within this gene cluster were associated with AD at TTC12 (markers rs1893699-rs723077) in both the case-control and family-based samples, as well as variants around exon 12 of NCAMI and exons 2 and 5 of ANKK1 only in the case-control sample. For DD, two separate association studies of $\mathrm{AD}$ with $\mathrm{DD}(\mathrm{AD}+\mathrm{DD})$ and $\mathrm{AD}$ without $\mathrm{DD}$ (AD-only) in 1,090 individuals of EAs were performed using the aforementioned designs and the same genetic variants (Yang et al. 2008). More evidence was provided for the association of haplotypic variants in exon 3 of TTC12, exon 12 of NCAM1, and the two $3^{\prime}$-ends of $A N K K 1$ and $D R D 2$ as co-effectors of $\mathrm{AD}$ and DD.

It is intriguing that variants within the NCAM1-TTC12$A N K K 1-D R D 2$ gene cluster were also found to be strongly associated with nicotine dependence (ND) in two independent American populations, consisting of 1,615 individuals from AA and EA ancestry (Gelernter et al. 2006). These individuals were based on affected sibling pairs with cocaine or opioid dependence. Forty-three SNPs were genotyped (see above). Of these, four markers (rs4938012, rs4938013, rs4938015, and rs11604671) located in the ANKK1 gene were significantly associated with ND in EA, and only the first two markers reached nominal significance in AA. In TTC12, the most statistically significant marker was $\mathrm{rs} 2303380(P<0.0007$ in AAs; $P<0.007$ in EAs $)$. Haplotype analyses performed on the most significantly associated markers (rs2303380, rs4938012, rs4938015, and rs11604671) demonstrated a significant association of this SNP combination with ND in the individual $(P<0.0003$ for AAs; $P<0.0008$ for EAs) and pooled $(P<0.000005)$ samples. Furthermore, the GATC haplotype was associated with ND (EAs: $P<0.00006$; AAs: $P<0.0008$; pooled: $P<0.0000001)$ showing strong evidence for association of the same haplotype with ND. In these two distinct populations, the AGCT and AGTC haplotypes were associated with decreased risk of ND (EAs: $P<0.001$; AAs: $P<0.0009$ ) (Gelernter et al. 2006).

Evidence of a genetic network underlying ADHD, CD, ODD, and SUD

In order to contrast the main hypothesis of the manuscript, i.e., the existence of a network of genes underlying these
Table 2 Genes overrepresented in gene ontology (GO) networks involving the LPHN3, NCAM1, TTC12, ANKK1, DRD2, and CDH13 genes

\begin{tabular}{|c|c|}
\hline Gene & Name \\
\hline SLC6A3 & $\begin{array}{l}\text { Solute carrier family } 6 \text { (neurotransmitter transporter, } \\
\text { dopamine), member } 3\end{array}$ \\
\hline ST8SIA3 & $\begin{array}{l}\text { ST8 alpha-N-acetyl-neuraminide alpha-2,8- } \\
\text { sialyltransferase } 3\end{array}$ \\
\hline ST8SIA2 & $\begin{array}{l}\text { ST8 alpha-N-acetyl-neuraminide alpha-2,8- } \\
\text { sialyltransferase } 2\end{array}$ \\
\hline ST8SIA4 & $\begin{array}{l}\text { ST8 alpha-N-acetyl-neuraminide alpha-2,8- } \\
\text { sialyltransferase } 4\end{array}$ \\
\hline$P P P 1 R 9 B$ & Protein phosphatase 1 , regulatory (inhibitor) subunit 9B \\
\hline$A D I P O Q$ & Adiponectin, C1Q and collagen domain containing \\
\hline GFRA1 & GDNF family receptor alpha 1 \\
\hline FGFR1 & Fibroblast growth factor receptor 1 \\
\hline$A D O R A 2 A$ & Adenosine A2a receptor \\
\hline GDNF & Glial cell derived neurotrophic factor \\
\hline$P R N P$ & Prion protein \\
\hline NCS1 & Neuronal calcium sensor 1 \\
\hline$A G A$ & Aspartylglucosaminidase \\
\hline CLIC6 & Chloride intracellular channel 6 \\
\hline$A G R N$ & Agrin \\
\hline GIPC1 & GIPC PDZ domain containing family, member 1 \\
\hline$M D K$ & Midkine (neurite growth-promoting factor 2) \\
\hline$H O X B 8$ & Homeobox B8 \\
\hline$N C A N$ & Neurocan \\
\hline KCNJ3 & $\begin{array}{l}\text { Potassium inwardly-rectifying channel, subfamily J, } \\
\text { member } 3\end{array}$ \\
\hline ZNF24 & Zinc finger protein 24 \\
\hline$F G F R 2$ & Fibroblast growth factor receptor 2 \\
\hline KCNJ5 & $\begin{array}{l}\text { Potassium inwardly-rectifying channel, subfamily } \mathrm{J} \text {, } \\
\text { member } 5\end{array}$ \\
\hline CADPS & $\mathrm{Ca}^{++}$-dependent secretion activator \\
\hline KCNJ6 & $\begin{array}{l}\text { Potassium inwardly-rectifying channel, subfamily } \mathrm{J} \text {, } \\
\text { member } 6\end{array}$ \\
\hline$M P D Z$ & Multiple PDZ domain protein \\
\hline$C A D P S 2$ & $\mathrm{Ca}^{++}$-dependent secretion activator 2 \\
\hline GNAZ & $\begin{array}{l}\text { Guanine nucleotide binding protein ( } \mathrm{G} \text { protein), } \\
\text { alpha z polypeptide }\end{array}$ \\
\hline PCDH17 & Protocadherin 17 \\
\hline НОХА5 & Homeobox A5 \\
\hline
\end{tabular}

complex phenotypes, we performed a formal network analysis with the LPHN3, NCAM1, TTC12, ANKK1, $D R D 2$, and $C D H 13$ genes, a set of significantly replicated genes either associated and/or linked to ADHD, disruptive behaviors, and SUD (Table 1). In addition, in order to detect significantly enriched gene categories within this set of genes, we performed analyses with the GeneMANIA Pathway Analysis software (http://genemania.org/). GeneMANIA uses a large set of available functional association 


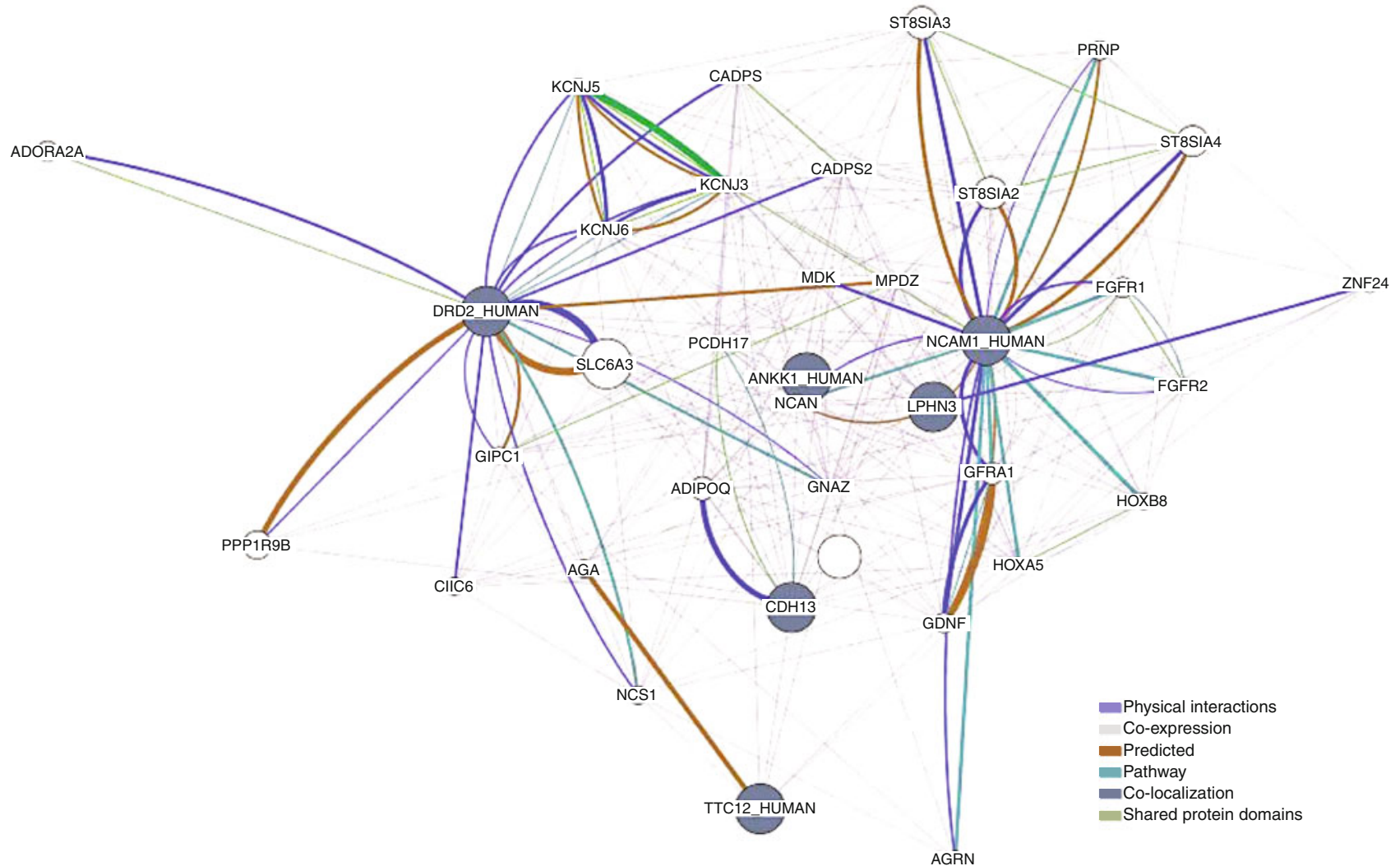

Fig. 7 Results from a formal network analysis using the ANKK1, TTC12, DRD2, NCAM1, LPHN3, and CDH13 genes in order to detect significantly enriched gene categories for protein and genetic interactions, pathways, co-expression, co-localization and protein domain similarity. These selected genes were significantly replicated

Table 3 Gene ontology (GO) networks overrepresented when considering the LPHN3, NCAM1, TTC12, ANKK1, DRD2, and CDH13 genes

\begin{tabular}{lll}
\hline GO ID & Description & $q$ value \\
\hline 0007411 & Axon guidance & $1.90 \times 10^{-5}$ \\
0050804 & Regulation of synaptic transmission & $3.97 \times 10^{-3}$ \\
0005242 & Inward rectifier potassium channel activity & $4.32 \times 10^{-3}$ \\
0051969 & $\begin{array}{l}\text { Regulation of transmission of nerve } \\
\text { impulse }\end{array}$ & $4.32 \times 10^{-3}$ \\
0031644 & Regulation of neurological system process & $4.32 \times 10^{-3}$ \\
0008373 & Sialyltransferase activity & $4.68 \times 10^{-3}$ \\
0051937 & Catecholamine transport & $5.01 \times 10^{-3}$ \\
0015844 & Monoamine transport & $1.18 \times 10^{-2}$ \\
0015850 & Organic alcohol transport & $2.79 \times 10^{-2}$ \\
0034705 & Potassium channel complex & $3.59 \times 10^{-2}$ \\
0008076 & Voltage-gated potassium channel complex & $3.59 \times 10^{-2}$ \\
0005249 & Voltage-gated potassium channel activity & $3.59 \times 10^{-2}$ \\
\hline
\end{tabular}

data for protein and genetic interactions, pathways, coexpression, co-localization, and protein domain similarity. We found additional genes in pathways (Table 2 and as being either associated and/or linked to ADHD, disruptive behaviors and SUD. Networks related to pathways involved in processes such as axon guidance, regulation of synaptic transmission and regulation of transmission of nerve impulse were overrepresented. For more information see Tables 2 and 3

Fig. 7), as well as functions that frame these apparently unrelated genes to statistically significant gene ontology (GO) networks related to pathways, such as axon guidance, regulation of synaptic transmission, and regulation of transmission of nerve impulse, among others (Table 3).

These results are compatible with other network analyses that used the most highly ADHD-associated genes, which found that they encode proteins involved in directed neurite outgrowth (Poelmans et al. 2011). With this additional data, we show that common genetic variants harbored in the LPHN3, NCAM1, TTC12, ANKK1, DRD2, and $\mathrm{CDH} 13$ genes, known to predispose to ADHD and to disruptive behavior symptoms present in ODD, CD, and SUD, are overrepresented in a network of genes ontologically linked to neurodevelopment. Future deep sequencing of the genomic regions harboring these variants will allow us to define true functional causal mutations. Identified common and rare genetic variants, together with clinical covariate information, plus data of brain function provided by fMRI, will in the future provide a predictive framework suitable to be used in clinical assessment and prevention of these common behavioral disorders. 
Acknowledgments The authors would like to extend their deepest gratitude to all patients and families who took part in our research on ADHD. The authors want to especially thank Julia Fekecs who provided invaluable graphical assistance with figures. This research was supported by the Division of Intramural Research, National Human Genome Research Institute, National Institutes of Health, Department of Health and Human Services, USA.

Conflict of interest The authors declare no competing financial interests.

Open Access This article is distributed under the terms of the Creative Commons Attribution License which permits any use, distribution, and reproduction in any medium, provided the original author(s) and the source are credited.

\section{References}

Acosta MT, Arcos-Burgos M, Muenke M (2004) Attention deficit/ hyperactivity disorder (ADHD): complex phenotype, simple genotype? Genet Med 6:1-15. doi:10.1097/01.GIM.0000110413. 07490.0B

Acosta MT, Vélez JI, Bustamante ML, Balog JZ, Arcos-Burgos M, Muenke M (2011) A two-locus genetic interaction between LPHN3 and $11 \mathrm{q}$ predicts ADHD severity and long-term outcome. Transl Psychiatry 1:e17

American Psychiatric Association (2000) Diagnostic and statistical manual of mental disorders, 4th edn. American psychiatric Association, Washington, DC

Anaya JM (2010) The autoimmune tautology. Arthritis Res Ther 12:147. doi:10.1186/ar3175

Arcos-Burgos M, Muenke M (2010) Toward a better understanding of ADHD: LPHN3 gene variants and the susceptibility to develop ADHD. Atten Defic Hyperact Disord 2:139-147. doi:10.1007/ s12402-010-0030-2

Arcos-Burgos M, Castellanos FX, Konecki D, Lopera F, Pineda D, Palacio JD, Rapoport JL, Berg K, Bailey-Wilson J, Muenke M (2004a) Pedigree disequilibrium test (PDT) replicates association and linkage between DRD4 and ADHD in multigenerational and extended pedigrees from a genetic isolate. Mol Psychiatry 9:252-259. doi:10.1038/sj.mp.4001396

Arcos-Burgos M, Castellanos FX, Pineda D, Lopera F, Palacio JD, Palacio LG, Rapoport JL, Berg K, Bailey-Wilson JE, Muenke M (2004b) Attention-deficit/hyperactivity disorder in a population isolate: linkage to loci at $4 \mathrm{q} 13.2,5 \mathrm{q} 33.3,11 \mathrm{q} 22$, and $17 \mathrm{p} 11$. Am J Hum Genet 75:998-1014. doi:10.1086/426154

Arcos-Burgos M, Jain M, Acosta MT, Shively S, Stanescu H, Wallis D, Domene S, Velez JI, Karkera JD, Balog J, Berg K, Kleta R, Gahl WA, Roessler E, Long R, Lie J, Pineda D, Londono AC, Palacio JD, Arbelaez A, Lopera F, Elia J, Hakonarson H, Johansson S, Knappskog PM, Haavik J, Ribases M, Cormand B, Bayes M, Casas M, Ramos-Quiroga JA, Hervas A, Maher BS, Faraone SV, Seitz C, Freitag CM, Palmason H, Meyer J, Romanos M, Walitza S, Hemminger U, Warnke A, Romanos J, Renner T, Jacob C, Lesch KP, Swanson J, Vortmeyer A, BaileyWilson JE, Castellanos FX, Muenke M (2010) A common variant of the latrophilin 3 gene, LPHN3, confers susceptibility to ADHD and predicts effectiveness of stimulant medication. Mol Psychiatry 15:1053-1066. doi:10.1038/mp.2010.6

Bergen AW, Korczak JF, Weissbecker KA, Goldstein AM (1999) A genome-wide search for loci contributing to smoking and alcoholism. Genet Epidemiol 17(Suppl 1):S55-S60

Biederman J, Wilens T, Mick E, Milberger S, Spencer TJ, Faraone SV (1995) Psychoactive substance use disorders in adults with attention deficit hyperactivity disorder (ADHD): effects of ADHD and psychiatric comorbidity. Am J Psychiatry 152:16521658

Bukstein O (2008) Substance abuse in patients with attention-deficit/ hyperactivity disorder. Medscape J Med 10:24

Castellanos FX, Tannock R (2002) Neuroscience of attention-deficit/ hyperactivity disorder: the search for endophenotypes. Nat Rev Neurosci 3:617-628. doi:10.1038/nrn896

Chambers RA, Taylor JR, Potenza MN (2003) Developmental neurocircuitry of motivation in adolescence: a critical period of addiction vulnerability. Am J Psychiatry 160:1041-1052

David SP, Mezuk B, Zandi PP, Strong D, Anthony JC, Niaura R, Uhl GR, Eaton WW (2010) Sex differences in TTC12/ANKK1 haplotype associations with daily tobacco smoking in Black and White Americans. Nicotine Tob Res 12:251-262. doi:10.1093/ ntr/ntp201

DeMilio L (1989) Psychiatric syndromes in adolescent substance abusers. Am J Psychiatry 146:1212-1214

Ducci F, Kaakinen M, Pouta A, Hartikainen AL, Veijola J, Isohanni M, Charoen P, Coin L, Hoggart C, Ekelund J, Peltonen L, Freimer N, Elliott P, Schumann G, Jarvelin MR (2011) TTC12ANKK1-DRD2 and CHRNA5-CHRNA3-CHRNB4 influence different pathways leading to smoking behavior from adolescence to mid-adulthood. Biol Psychiatry 69:650-660. doi: 10.1016/j.biopsych.2010.09.055

Elia J, Arcos-Burgos M, Bolton KL, Ambrosini PJ, Berrettini W, Muenke M (2009) ADHD latent class clusters: DSM-IV subtypes and comorbidity. Psychiatry Res 170:192-198. doi: 10.1016/j.psychres.2008.10.008

Ercan ES, Coskunol H, Varan A, Toksoz K (2003) Childhood attention deficit/hyperactivity disorder and alcohol dependence: a 1-year follow-up. Alcohol Alcohol 38:352-356

Gelernter J, Yu Y, Weiss R, Brady K, Panhuysen C, Yang BZ, Kranzler HR, Farrer L (2006) Haplotype spanning TTC12 and ANKK1, flanked by the DRD2 and NCAM1 loci, is strongly associated to nicotine dependence in two distinct American populations. Hum Mol Genet 15:3498-3507. doi:10.1093/hmg/dd1426

Hinney A, Scherag A, Jarick I, Albayrak O, Putter C, Pechlivanis S, Dauvermann MR, Beck S, Weber H, Scherag S, Nguyen TT, Volckmar AL, Knoll N, Faraone SV, Neale BM, Franke B, Cichon S, Hoffmann P, Nothen MM, Schreiber S, Jockel KH, Wichmann HE, Freitag C, Lempp T, Meyer J, Gilsbach S, Herpertz-Dahlmann B, Sinzig J, Lehmkuhl G, Renner TJ, Warnke A, Romanos M, Lesch KP, Reif A, Schimmelmann BG, Hebebrand J (2011) Genome-wide association study in German patients with attention deficit/hyperactivity disorder. Am J Medical Genet Part B Neuropsychiatr Genet 156B: 888-897. doi:10.1002/ajmg.b.31246

Horner BR, Scheibe KE (1997) Prevalence and implications of attention-deficit hyperactivity disorder among adolescents in treatment for substance abuse. J Am Acad Child Adolesc Psychiatry 36:30-36

Jain M, Palacio LG, Castellanos FX, Palacio JD, Pineda D, Restrepo MI, Munoz JF, Lopera F, Wallis D, Berg K, Bailey-Wilson JE, Arcos-Burgos M, Muenke M (2007) Attention-deficit/hyperactivity disorder and comorbid disruptive behavior disorders: evidence of pleiotropy and new susceptibility loci. Biol Psychiatry 61:1329-1339. doi:10.1016/j.biopsych.2006.06.026

Jain M, Velez JI, Acosta MT, Palacio LG, Balog J, Roessler E, Pineda D, Londono AC, Palacio JD, Arbelaez A, Lopera F, Elia J, Hakonarson H, Seitz C, Freitag CM, Palmason H, Meyer J, Romanos M, Walitza S, Hemminger U, Warnke A, Romanos J, Renner T, Jacob C, Lesch KP, Swanson J, Castellanos FX, Bailey-Wilson JE, Arcos-Burgos M, Muenke M (2011) A cooperative interaction between LPHN3 and 11q doubles the risk for ADHD. Mol Psychiatry. doi:10.1038/mp.2011.59 
Jin Y, Birlea SA, Fain PR, Gowan K, Riccardi SL, Holland PJ, Mailloux CM, Sufit AJ, Hutton SM, Amadi-Myers A, Bennett DC, Wallace MR, McCormack WT, Kemp EH, Gawkrodger DJ, Weetman AP, Picardo M, Leone G, Taieb A, Jouary T, Ezzedine K, van Geel N, Lambert J, Overbeck A, Spritz RA (2010) Variant of TYR and autoimmunity susceptibility loci in generalized vitiligo. N Engl J Med 362:1686-1697. doi: 10.1056/NEJMoa0908547

Johnson C, Drgon T, Liu QR, Walther D, Edenberg H, Rice J, Foroud T, Uhl GR (2006) Pooled association genome scanning for alcohol dependence using 104,268 SNPs: validation and use to identify alcoholism vulnerability loci in unrelated individuals from the collaborative study on the genetics of alcoholism. Am J Med Genet B Neuropsychiatr Genet 141B:844-853. doi: 10.1002/ajmg.b.30346

Karkowski LM, Prescott CA, Kendler KS (2000) Multivariate assessment of factors influencing illicit substance use in twins from female-female pairs. Am J Med Genet 96:665-670. doi: 10.1002/1096-8628(20001009)96:5

Khantzian EJ (1997) The self-medication hypothesis of substance use disorders: a reconsideration and recent applications. Harv Rev Psychiatry 4:231-244

Kuperman S, Schlosser SS, Kramer JR, Bucholz K, Hesselbrock V, Reich T, Reich W (2001) Developmental sequence from disruptive behavior diagnosis to adolescent alcohol dependence. Am J Psychiatry 158:2022-2026

Li MD, Burmeister M (2009) New insights into the genetics of addiction. Nat Rev Genet 10:225-231. doi:10.1038/nrg2536

Liu QR, Drgon T, Johnson C, Walther D, Hess J, Uhl GR (2006) Addiction molecular genetics: 639,401 SNP whole genome association identifies many "cell adhesion" genes. Am J Med Genet B Neuropsychiatr Genet 141B:918-925. doi:10.1002/ ajmg.b.30436

Long JC, Knowler WC, Hanson RL, Robin RW, Urbanek M, Moore E, Bennett PH, Goldman D (1998) Evidence for genetic linkage to alcohol dependence on chromosomes 4 and 11 from an autosomewide scan in an American Indian population. Am J Med Genet 81:216-221. doi:10.1002/(SICI)1096-8628(19980508)81:3

Martin ER, Monks SA, Warren LL, Kaplan NL (2000) A test for linkage and association in general pedigrees: the pedigree disequilibrium test. Am J Hum Genet 67:146-154. doi: $10.1086 / 302957$

Martinez AF, Muenke M, Arcos-Burgos M (2011) From the black widow spider to human behavior: Latrophilins, a relatively unknown class of $\mathrm{G}$ protein-coupled receptors, are implicated in psychiatric disorders. Am J Med Genet B Neuropsychiatr Genet 156:1-10. doi:10.1002/ajmg.b.31137

Molina BS, Pelham WE Jr (2003) Childhood predictors of adolescent substance use in a longitudinal study of children with ADHD. J Abnorm Psychol 112:497-507

Molina BSG, Bradley HS, Pelham WE (1999) Interactive effects of attention deficit hyperactivity disorder and conduct disorder on early adolescent substance use. Psychol Addict Behav 13:348-358

Neale BM, Medland S, Ripke S, Anney RJ, Asherson P, Buitelaar J, Franke B, Gill M, Kent L, Holmans P, Middleton F, Thapar A, Lesch KP, Faraone SV, Daly M, Nguyen TT, Schafer H, Steinhausen HC, Reif A, Renner TJ, Romanos M, Romanos J, Warnke A, Walitza S, Freitag C, Meyer J, Palmason H, Rothenberger A, Hawi Z, Sergeant J, Roeyers H, Mick E, Biederman J (2010) Case-control genome-wide association study of attention-deficit/hyperactivity disorder. J Am Acad Child Adolesc Psychiatry 49:906-920. doi:10.1016/j.jaac.2010.06.007

Palacio JD, Castellanos FX, Pineda DA, Lopera F, Arcos-Burgos M, Quiroz YT, Henao GC, Puerta IC, Ramirez DL, Rapoport JL, Bailey-Wilson J, Berg K, Muenke M (2004) Attention-deficit/ hyperactivity disorder and comorbidities in 18 Paisa Colombian multigenerational families. J Am Acad Child Adolesc Psychiatry 43:1506-1515 pii: 00004583-200412000-00008

Pelham WE, Foster EM, Robb JA (2007) The economic impact of attention-deficit/hyperactivity disorder in children and adolescents. J Pediatr Psychol 32:711-727

Pineda DA, Lopera F, Puerta IC, Trujillo-Orrego N, Aguirre-Acevedo DC, Hincapie-Henao L, Arango CP, Acosta MT, Holzinger SI, Palacio JD, Pineda-Alvarez DE, Velez JI, Martinez AF, Lewis JE, Muenke M, Arcos-Burgos M (2011) Potential cognitive endophenotypes in multigenerational families: segregating ADHD from a genetic isolate. Atten Defic Hyperact Disord. doi: 10.1007/s12402-011-0061-3

Poelmans G, Pauls DL, Buitelaar JK, Franke B (2011) Integrated genome-wide association study findings: identification of a neurodevelopmental network for attention deficit hyperactivity disorder. The American journal of psychiatry 168:365-377. doi: 10.1176/appi.ajp.2010.10070948

Reich T, Edenberg HJ, Goate A, Williams JT, Rice JP, Van Eerdewegh P, Foroud T, Hesselbrock V, Schuckit MA, Bucholz K, Porjesz B, Li TK, Conneally PM, Nurnberger JI Jr, Tischfield JA, Crowe RR, Cloninger CR, Wu W, Shears S, Carr K, Crose C, Willig C, Begleiter H (1998) Genome-wide search for genes affecting the risk for alcohol dependence. Am J Med Genet 81:207-215. doi:10.1002/(SICI)1096-8628(19980508)81:3

Ribases M, Ramos-Quiroga JA, Sanchez-Mora C, Bosch R, Richarte V, Palomar G, Gastaminza X, Bielsa A, Arcos-Burgos M, Muenke M, Castellanos FX, Cormand B, Bayes M, Casas M (2010) Contribution of LPHN3 to the genetic susceptibility to ADHD in adulthood: a replication study. Genes Brain Behav 10:149-157. doi:10.1111/j.1601-183X.2010.00649.x

Ribases M, Ramos-Quiroga JA, Sanchez-Mora C, Bosch R, Richarte V, Palomar G, Gastaminza X, Bielsa A, Arcos-Burgos M, Muenke M, Castellanos FX, Cormand B, Bayes M, Casas M (2011) Contribution of LPHN3 to the genetic susceptibility to ADHD in adulthood: a replication study. Genes Brain Behav 10:149-157. doi:10.1111/j.1601-183X.2010.00649.x

Spritz RA (2011) Recent progress in the genetics of generalized vitiligo. J Genet Genomics 38:271-278. doi:10.1016/j.jgg.2011. 05.005

Stanescu HC, Arcos-Burgos M, Medlar A, Bockenhauer D, Kottgen A, Dragomirescu L, Voinescu C, Patel N, Pearce K, Hubank M, Stephens HA, Laundy V, Padmanabhan S, Zawadzka A, Hofstra JM, Coenen MJ, den Heijer M, Kiemeney LA, Bacq-Daian D, Stengel B, Powis SH, Brenchley P, Feehally J, Rees AJ, Debiec H, Wetzels JF, Ronco P, Mathieson PW, Kleta R (2011) Risk HLA-DQA1 and PLA(2)R1 alleles in idiopathic membranous nephropathy. N Engl J Med 364:616-626. doi:10.1056/NEJM oa1009742

Szobot CM, Rohde LA, Bukstein O, Molina BS, Martins C, Ruaro P, Pechansky F (2007) Is attention-deficit/hyperactivity disorder associated with illicit substance use disorders in male adolescents? A community-based case-control study. Addiction 102:1122-1130. doi:10.1111/j.1360-0443.2007.01850.x

True WR, Heath AC, Scherrer JF, Xian H, Lin N, Eisen SA, Lyons MJ, Goldberg J, Tsuang MT (1999) Interrelationship of genetic and environmental influences on conduct disorder and alcohol and marijuana dependence symptoms. Am J Med Genet 88:391-397. doi:10.1002/(SICI)1096-8628(19990820)88:4

Tsuang MT, Lyons MJ, Meyer JM, Doyle T, Eisen SA, Goldberg J, True W, Lin N, Toomey R, Eaves L (1998) Co-occurrence of abuse of different drugs in men: the role of drug-specific and shared vulnerabilities. Arch Gen Psychiatry 55:967-972

Uhl GR (2004a) Molecular genetic underpinnings of human substance abuse vulnerability: likely contributions to understanding addiction as a mnemonic process. Neuropharmacology 47(Suppl 1):140-147. doi:10.1016/j.neuropharm.2004.07.029 
Uhl GR (2004b) Molecular genetics of substance abuse vulnerability: remarkable recent convergence of genome scan results. Ann N Y Acad Sci 1025:1-13. doi:10.1196/annals.1316.001

Uhl GR, Liu QR, Walther D, Hess J, Naiman D (2001) Polysubstance abuse-vulnerability genes: genome scans for association, using 1,004 subjects and 1,494 single-nucleotide polymorphisms. Am J Hum Genet 69:1290-1300. doi:10.1086/324467

Uhl GR, Drgon T, Johnson C, Fatusin OO, Liu QR, Contoreggi C, Li CY, Buck K, Crabbe J (2008a) "Higher order" addiction molecular genetics: convergent data from genome-wide association in humans and mice. Biochem Pharmacol 75:98-111. doi: 10.1016/j.bcp.2007.06.042

Uhl GR, Drgon T, Liu QR, Johnson C, Walther D, Komiyama T, Harano M, Sekine Y, Inada T, Ozaki N, Iyo M, Iwata N, Yamada M, Sora I, Chen CK, Liu HC, Ujike H, Lin SK (2008b) Genomewide association for methamphetamine dependence: convergent results from 2 samples. Arch Gen Psychiatry 65:345-355. doi: 10.1001/archpsyc.65.3.345

Visser S, Bitsko R, Danielson M, Perou R (2010) Increasing Prevalence of Parent-Reported Attention-Deficit/Hyperactivity Disorder Among Children - United States, 2003 and 2007. Mortal Morb Wkly Rep 59:1439-1443
White AM, Jordan JD, Schroeder KM, Acheson SK, Georgi BD, Sauls G, Ellington RR, Swartzwelder HS (2004) Predictors of relapse during treatment and treatment completion among marijuana-dependent adolescents in an intensive outpatient substance abuse program. Subst Abus 25:53-59

Wilens TE, Biederman J (2006) Alcohol, drugs, and attention-deficit/ hyperactivity disorder: a model for the study of addictions in youth. J Psychopharmacol 20:580-588. doi:10.1177/0269881105058776

Wilens TE, Faraone SV, Biederman J, Gunawardene S (2003) Does stimulant therapy of attention-deficit/hyperactivity disorder beget later substance abuse? A meta-analytic review of the literature. Pediatrics 111:179-185

Yang BZ, Kranzler HR, Zhao H, Gruen JR, Luo X, Gelernter J (2007) Association of haplotypic variants in DRD2, ANKK1, TTC12 and NCAM1 to alcohol dependence in independent case control and family samples. Hum Mol Genet 16:2844-2853. doi: $10.1093 / \mathrm{hmg} / \mathrm{ddm} 240$

Yang BZ, Kranzler HR, Zhao H, Gruen JR, Luo X, Gelernter J (2008) Haplotypic variants in DRD2, ANKK1, TTC12, and NCAM1 are associated with comorbid alcohol and drug dependence. Alcohol Clin Exp Res 32:2117-2127. doi:10.1111/j.1530-0277.2008. 00800.x 